\section{Quality of Life Assessment in Children with Cerebral Palsy ORIGINAL}

Mirna A Frota', Viviane M Vasconcelos', Maria Teresa M Valdés ${ }^{3}$, Vanessa Gomes S Queiroz ${ }^{4}$, Karla Maria C Rolim ${ }^{1}$, Carlos A Bruno da Silva ${ }^{1}$

\section{Abstract}

Objectives: Evaluate the QoL of children with CP followed at Núcleo de Tratamento e Estimulação Precoce, in Fortaleza, Ceará, Brazil; identify the most affected domains of the Pediatric Quality of Life Inventory.

Methods: This was a cross-sectional, of which target population consisted of parents of children with CP $(N=62)$. Data collection was carried out by applying the socioeconomic questionnaire and the Health-related Quality of Life tool - HRQoL-PedsQL version 4.0, module applied to parents. Data analysis was performed with SPSS statistical software, version 23.0.

Results: The results after transformation of scores into a scale of 0 to 100 in PedsQL, the data showed statistical difference between QOL domains except for physical capacity and social aspect and in descending order of impairment, the domains were related to school activity, the emotional aspect, physical capacity and the social aspect.

Conclusions: Given the above, to attain improvement in QoL indicators, it is reasonable to propose interdisciplinary intervention among healthcare professionals in order to develop improved strategies aiming to promote early integration of children with CP in schools, to obtain significant results.

\section{Introduction}

Advances in the medical area have allowed the increased survival of children with chronic diseases, but they do not guarantee a satisfactory quality of life (QOL). It is clear the need to address the QoL of children with Cerebral Palsy (CP), considering the disease affects their well-being. Cerebral palsy (CP) represents a group of chronic, non-
1 Universidade de Fortaleza (UNIFOR). Fortaleza, CE, Brazil.

2 Universidade Federal do Ceará (UFC). Fortaleza, CE, Brazil.

3 Equipe de Inovação Social da Fundação LEIA/Tecnalia Research and Innovation. Spain.

4 Universidade Federal de Natal (UFRN). Natal, RN, Brazil.

\section{Contact information:}

\section{Carlos Antonio Bruno da Silva.}

Address: Universidade de Fortaleza. Av Washington Soares, 1231. Bloco S Sala S 01. Edson Queiroz, Fortaleza. Ceara. CEP 60881-904.

Tel: 0055(85)34773280.

”carlosbruno@unifor.br

Keywords

Quality of Life; Children with Disabilities; Cerebral Palsy. 
progressive, but often changing disorders secondary to brain dysgenesis or injury. It is characterized by significant impairment in movement and posture that begins during infancy or early childhood [1]. CP affects approximately two to three in 1000 live births in the United States and is the leading cause of motor disability in children. The motor variations are usually accompanied by disorders in perception, cognition, communication and/or behaviors and/or seizures [2]. These aspects influence the capacity of the child with CP to develop activities of daily living, which may result in significant alterations in quality of life.

Quality of Life (QoL) is defined as the individual's perception in relation to his position in life, in the context of culture and value system in which he lives and in relation to his objectives, expectations, standards and concerns of life [3]. In children, QoL has been defined subjectively and at a multidimensional level, including functional capacity and the child/family psychosocial interaction. Thus, every child has the right to a good quality of life and to have their needs met. However, it is emphasized that the quality of living standards are often not respected, hence the importance of the evaluation of the child's QOL, especially the ones that have an associated pathology $[4,5]$.

By identifying the most affected QOL domains, it is possible to relinquish the curative model and establish strategies focused on promoting health in an interdisciplinary approach, with the aim of improving the QOL of these children, resulting in reduced costs for public health care.

Therefore, the measurement of $\mathrm{QoL}$ is a relevant health indicator, as it provides information on how the clinical condition affects the patient's life and directs public policies aimed at improving QOL. The National Policy on Health Promotion (PNPS) emphasizes the search for equity and proposes promoting QOL and reducing health risks related to conditioning factors - way of life, working conditions, housing, environment, education, leisure, culture, access to goods and essential services $[6,7]$.
As diseases have different effects on an individual's life, the definition of the term "health" becomes complex, considering the several aspects concerning life in society. Therefore, to classify health as good, bad or fair is primarily a way to define QOL, as it derives from the social class status, relations at work, food, housing, basic sanitation, healthy environment, access to education, transport, leisure, health services, in short, everything that concerns life [8].

From the perspective of health promotion, it will be possible to plan the development of interventions aimed at the health characteristics inherent to these children. Given the above, we see the relevance of evaluating $\mathrm{QOL}$ in children with $\mathrm{CP}$, so that it will be possible to offer better health care, which will involve different professionals, with an interdisciplinary approach, thus improving the QOL standards of these patients.

Thus, the aim of this study was to evaluate the QoL of children with CP treated at Núcleo de Tratamento e Estimulação Precoce (NUTEP) and identify the most affected domains of the Pediatric Quality of Life Inventory (PedsQL)[9].

\section{Methods}

This is a descriptive, cross-sectional study, with a quantitative approach. The sample consisted of 62 parents of children with $C P$, aged two to seven years, as this is the age range used in the QOL assessment questionnaire of children with CP - PedsQL version 4.0, the module applied to parents, for in due to the delay in the neurological development of most children with $\mathrm{CP}$, data collection instruments were answered by parents. The study included parents of children with confirmed medical diagnosis of PC followed at NUTEP during the data collection period, whose main caregiver was the father or mother of the child, able to provide the necessary information for data collection.

NUTEP is a non-profit institution, located in the Hospital Complex of the School of Medicine of Uni- 
versidade Federal do Ceará (UFC). Data collection was carried out using two tools: a socioeconomic file, with data reported by the study informants (parents) on age, education, income, occupation, religion, number of children, and with respect to children with $C P$, the information provided included gender, age and disease-related data. To evaluate Health-Related Quality of Life (HRQOL), PedsQL 4.0, a generic tool, validated in Brazil for use with parents - PedsQL 4.0[10] was used. The version to be used with parents of children aged 2-4 years old consists of 21 items, containing the physical, emotional and social domains, while the version for the age group between 5 and 7 years, consists of 23 items, which includes the same questions in the earlier version, plus the items related to the school domain.

Each domain is represented by different variables and questions are formulated for a Likert-type response scale, in which the following question was asked: "How often, in the last month, has your child had problems with .....". For analysis of the tools, a five-point response scale is used $(0=$ is never a problem; 1 = is almost never a problem; 2 = is sometimes a problem; $3=$ is often a problem and 4 $=$ is almost always a problem [9].

The physical capacity domain consists of: parental perception of their child's physical condition. It contains questions related to pain and discomfort; energy; activities of daily living. The emotional domain involves: the parents' perception regarding their child's emotional condition, of which variables are: sleep and rest, self-esteem; negative feelings; spirituality/religion/personal beliefs.

The social domain includes: parents' perception of their child's social relationships and their social roles, with questions about personal relationships; capacity to socialize, social support. The school domain includes the parents' perception of several aspects related to the child's school environment and comprises: thinking, learning, memory, concentration and health status 9.
The items are reverse-score and linearly transformed to a scale from 0 to $100(0=100,1=75,2=$ $50,3=25,4=0)$. Therefore, higher scores indicate better QoL. The scale scores were computed as the sum of the items divided by the number of answered items (considering missing data). If more than $50 \%$ of the items on the scale were not answered, it was not computed [9].

The Statistical Package for Social Sciences (SPSS), version 23.0, was used for the analysis, organization, coding and tabulation of the quantitative data. Descriptive statistics were used to characterize the sample in relation to socioeconomic data and PedsQL scores. Some children did not attend daycare and/or kindergarten; therefore, regarding the school domain, some parents could not answer the questions. Of the total of 62 children, 24 answered the questions. Kendall and Friedman's nonparametric test was used for this portion that answered the questions related to the school domain.

ANOVA was applied to the informants answers. The significance level was set at $p \leq 0.01$. The data are shown in tables and the discussion was based on the pertinent literature.

The study was approved by the Research Ethics Committee of Universidade de Fortaleza/UNIFOR (Edict N. 069/2009). It is noteworthy that the informants were contacted, received information on the study objectives, signed the Free and Informed Consent form and provided relevant information. The interview was conducted only after the free and informed consent was obtained from the interviewee.

\section{Results}

A total of 62 questionnaires were answered and described the socioeconomic data of children with $\mathrm{CP}$, as well as of the parents participating in the study. Subsequently, the children's QoL assessment was performed by applying the PedsQL questionnaire. 
About Socioeconomic characteristics of the parents and of the children, their age ranged from 19 to 63 years for the children's fathers, with a predominance of the age range of 20 to 39 years $(69.3 \%)$, with a mean age of $34.86(S D= \pm 8.92)$. For the mothers of the children with $\mathrm{CP}$, age ranged from 16 to 47 years, with a predominance of the age range of 20 to 39 years (82.3\%), with a mean age of 31.35 (SD = \pm 7.50 ).

As for the father's level of schooling, the data show they had predominantly 6-10 years of schooling (40.3\%) and more than 10 years (38.7\%). As for the mothers, 34 (54\%) had more than 10 years of study, showing they dedicated more time to education.

Most parents of children with CP, 43 (69.4\%), had a common-law marriage, although it was relevant the number of parents who did not live together, but shared the life of their child with $\mathrm{CP}$, corresponding to $30.6 \%$ of the sample.

Regarding the fathers' professions, they are quite diverse and most are employed (82.2\%). Most of the mothers, 41 (66.5\%), are homemakers. The families live with a mean income of $R \$ 1,135.53$, with a standard deviation of $\pm R \$ 735.69$, with a predominance of income between $\mathrm{R} \$ 465.00$ and $\mathrm{R} \$ 930.00$, which corresponds to two minimum wages at the time of the study, which, as reported by the study informants, would correspond to one wage received by the child as social benefit and the other from the father, who worked. Most of these families have between one and three children (88.7\%), with an average of four people living in the homes.

As for the religion of the informants, there was a predominance of Catholics, corresponding to 47 families (75.8\%), while 11 families (17.7\%) belonged to the evangelical denomination.

Of the total of 62 children, the majority, 46 $(74.2 \%)$ was treated at another location other than NUTEP, ranging from private physical therapy clinics, follow-up with neurologists on an outpatient basis and the Children's Rehabilitation Department of Centro de Reabilitação Sarah - Fortaleza, which, according to Miura (2007), treats children with brain and spinal cord lesions, myopathies, among others, with $\mathrm{CP}$ being the most frequently treated pathology at this department.

Regarding the children's preference of environments, according to their parents, they prefer the living room (64.5\%) and the bedroom (16.1\%); among the reasons for these preferences, the man one is that these environments have a TV set (58.1\%).

It is important to attain an early diagnosis of $C P$, so that interventions can be implemented by professionals as soon as possible, improving prognosis. The children in the study were diagnosed at different ages, ranging from birth to three years of age, with a predominance of diagnosis between the ages of two to six months (38.7\%) and seven months to one year (35.5\%).

Of the total sample, 53 (85.5\%) have no other CP cases in the family; only $9(14.5 \%)$ have a relative with $\mathrm{CP}$, ranging from siblings $(4.8 \%)$ to uncles $(1.6 \%)$ and cousins (4.8\%), among others.

About the Quality of Life Assessment of Children After transforming the scores into a 0-100 scale in the pediatric HRQOL questionnaire - PedsQL the mean for the different domains was calculated with the participants (62), resulting in 62.4 for school, 80.8 for the emotional aspect, 90.1 for physical capacity and 91.8 for the emotional aspect. These data demonstrate that the school domain was the most affected in the study population.

When applying the non-parametric Kendall and Friedman statistical tests to the 24 parents of children who answered the questionnaire, including the school domain, there was a statistical difference between the assessed QoL domains, with $p \leq 0.01$. Based on these results, the evolution of children with $C P$ in some domains, but not in others, was observed. 
Table 1. Frequency distribution of scores for physical functioning . Fortaleza. CE. Brasil $(\mathrm{N}=62)$.

\begin{tabular}{|c|c|c|c|c|c|c|c|c|c|c|}
\hline \multirow{2}{*}{$\begin{array}{l}\text { Physical Functioning } \\
\text { (problems with...) }\end{array}$} & \multicolumn{2}{|c|}{ Never } & \multicolumn{2}{|c|}{ Almost never } & \multicolumn{2}{|c|}{ Sometimes } & \multicolumn{2}{|c|}{ Often } & \multicolumn{2}{|c|}{ Almost always } \\
\hline & N & $\%$ & N & $\%$ & N & $\%$ & N & $\%$ & N & $\%$ \\
\hline Walking more than one block & 3 & 4.8 & 2 & 3.2 & 4 & 6.5 & 6 & 9.7 & 47 & 75.8 \\
\hline Running & 4 & 6.5 & - & - & 3 & 4.8 & 3 & 4.8 & 52 & 83.9 \\
\hline $\begin{array}{l}\text { Participating in sports activity or } \\
\text { exercise }\end{array}$ & 13 & 21 & 7 & 11.3 & 10 & 16.1 & 10 & 16.1 & 22 & 35.5 \\
\hline Lifting something heavy & 14 & 22.6 & 9 & 14.5 & 4 & 6.5 & 4 & 6.5 & 31 & 50 \\
\hline $\begin{array}{l}\text { Taking a bath or shower by him or } \\
\text { herself }\end{array}$ & 21 & 33.9 & 8 & 12.9 & 5 & 8.1 & 3 & 4.8 & 25 & 40.3 \\
\hline Doing chores around the house & 21 & 33.9 & 7 & 11.3 & 7 & 11.3 & 4 & 6.5 & 23 & 37.1 \\
\hline Having hurts or aches & 31 & 50 & 12 & 19.4 & 12 & 19.4 & 5 & 8.1 & 2 & 3.2 \\
\hline Low energy level & 43 & 69.4 & 6 & 9.7 & 8 & 12.9 & 4 & 6.5 & 1 & 1.6 \\
\hline Total & \multicolumn{2}{|c|}{150} & \multicolumn{2}{|c|}{51} & \multicolumn{2}{|c|}{53} & \multicolumn{2}{|c|}{39} & \multicolumn{2}{|c|}{203} \\
\hline
\end{tabular}

Table 2. Frequency distribution of scores for emotional functioning. Fortaleza. CE. Brasil $(\mathrm{N}=62)$.

\begin{tabular}{|c|c|c|c|c|c|c|c|c|c|c|}
\hline \multirow{2}{*}{$\begin{array}{l}\text { Emotional Functioning } \\
\text { (problems with...) }\end{array}$} & \multicolumn{2}{|c|}{ Never } & \multicolumn{2}{|c|}{ Almost never } & \multicolumn{2}{|c|}{ Sometimes } & \multicolumn{2}{|c|}{ Often } & \multicolumn{2}{|c|}{ Almost always } \\
\hline & N & $\%$ & N & $\%$ & N & $\%$ & N & $\%$ & N & $\%$ \\
\hline Feeling afraid or scared & 9 & 14.5 & 7 & 11.3 & 22 & 35.5 & 9 & 14.5 & 15 & 24.2 \\
\hline Feeling sad or blue & 32 & 51.6 & 15 & 24.2 & 12 & 19.4 & 2 & 3.2 & 1 & 1.6 \\
\hline Feeling angry & 6 & 9.7 & 7 & 11.3 & 35 & 56.5 & 10 & 16.1 & 4 & 6.5 \\
\hline Trouble sleeping & 34 & 54.8 & 4 & 6.5 & 4 & 6.5 & 4 & 6.5 & 16 & 25.8 \\
\hline $\begin{array}{l}\text { Worrying about what will happen to } \\
\text { him or her }\end{array}$ & 38 & 61.3 & 3 & 4.8 & 13 & 21 & 5 & 8.1 & 3 & 4.8 \\
\hline Feeling afraid or scared & \multicolumn{2}{|c|}{119} & \multicolumn{2}{|c|}{36} & \multicolumn{2}{|c|}{86} & \multicolumn{2}{|c|}{30} & \multicolumn{2}{|c|}{39} \\
\hline
\end{tabular}

The ANOVA test showed statistical difference between all the domains, except between physical capacity and the social aspect. The results showed that, in descending order of impairment, the areas were related to school activity, the emotional aspect, the physical capacity and the social aspect.

Table 2 shows the results related to the domain of physical well-being of PedsQL. Parents felt that walking and running had been a problem that "almost always" occurred with the children in the study, representing, respectively, 47 (75.8\%) and 52
(83.9\%), as children with CP are mostly confined to the lying and/or sitting position.

Briefly, on the problems related to pain or injuries, the findings indicated that the children "never" had problems with pain or injuries and had little energy, represented respectively by 31 (50\%) and $43(69.4 \%)$ of those who answered the questions. The children had no problems with pain or injuries, and little energy, because they only have alterations in the motor/ physical aspects, impairing the upper and/or lower limbs. 
Table 3 depicts the children's emotional wellbeing, showing diverse results regarding the aspect of feeling afraid or being scared. This is due to the participation of children aged 2-4 years, who, in most cases, cannot express their feelings, compromising the parents' perception at the time they answered the question.

The answers showed that the children often had problems regarding the aspect of feeling afraid or being scared, corresponding to 15 (24.2\%); however most "never" had difficulty sleeping (34; 54.8\%). Moreover, they sometimes had problems feeling angry $(35 ; 56.5 \%)$.

It characterizes the well-being of children with $C P$, in which most of them, 42 (67.7\%), "almost always" had problems in failing to perform activities that other children of the same age performed, as well as keeping up with their peers at playing, 38 (61.3\%). The fact is a result of the affected physical capacity, caused by the motor impairment of the upper limbs and especially the lower ones. For parents of children with $\mathrm{CP}$, their children playing with other children $(41 ; 66.1 \%)$ "almost never" was considered as a problem, as the disease allowed this interaction, not requiring the child's active participation (Table 4).

When parents reported that their children never had problems playing with other children (41; 66.1\%), the other children did not want to play with them (42; $67.7 \%)$ and other children teased their children $(48 ; 77.4 \%)$, which reflected the absence of prejudice caused by the disability of the child with CP.

Table 3. Frequency distribution of scores for social functioning. Fortaleza. CE. Brasil $(\mathrm{N}=62)$.

\begin{tabular}{|c|c|c|c|c|c|c|c|c|c|c|}
\hline \multirow{2}{*}{$\begin{array}{l}\text { Social Functioning } \\
\text { (problems with...) }\end{array}$} & \multicolumn{2}{|c|}{ Never } & \multicolumn{2}{|c|}{ Almost never } & \multicolumn{2}{|c|}{ Sometimes } & \multicolumn{2}{|c|}{ Often } & \multicolumn{2}{|c|}{ Almost always } \\
\hline & $\mathrm{N}$ & $\%$ & $\mathrm{~N}$ & $\%$ & $\mathrm{~N}$ & $\%$ & $\mathrm{~N}$ & $\%$ & $\mathrm{~N}$ & $\%$ \\
\hline Getting along with other children & 41 & 66.1 & 3 & 4.8 & 5 & 8.1 & 4 & 6.5 & 9 & 14.5 \\
\hline $\begin{array}{l}\text { Other kids not wanting to be his or } \\
\text { her friend }\end{array}$ & 42 & 67.7 & 8 & 12.9 & 6 & 9.7 & 2 & 3.2 & 4 & 6.5 \\
\hline Getting teased by other children & 48 & 77.4 & 5 & 8.1 & 5 & 8.1 & 2 & 3.2 & 2 & 3.2 \\
\hline $\begin{array}{l}\text { Not able to do things that other } \\
\text { children his or her age can do }\end{array}$ & 4 & 6.5 & 2 & 3.2 & 5 & 8.1 & 9 & 14.5 & 42 & 67.7 \\
\hline $\begin{array}{l}\text { Keeping up when playing with other } \\
\text { children }\end{array}$ & 6 & 9.7 & - & - & 6 & 9.7 & 12 & 19.4 & 38 & 61.3 \\
\hline Total & \multicolumn{2}{|c|}{141} & \multicolumn{2}{|c|}{18} & \multicolumn{2}{|c|}{27} & \multicolumn{2}{|c|}{29} & \multicolumn{2}{|c|}{95} \\
\hline
\end{tabular}

Table 4. Frequency distribution of scores for school functioning. Fortaleza. CE. Brasil ( $\mathrm{N}=39$ ).

\begin{tabular}{|c|c|c|c|c|c|c|c|c|c|c|}
\hline \multirow{2}{*}{$\begin{array}{l}\text { Social Functioning (problems } \\
\text { with...) }\end{array}$} & \multicolumn{2}{|c|}{ Never } & \multicolumn{2}{|c|}{ Almost never } & \multicolumn{2}{|c|}{ Sometimes } & \multicolumn{2}{|c|}{ Often } & \multicolumn{2}{|c|}{ Almost always } \\
\hline & $\mathrm{N}$ & $\%$ & $\mathrm{~N}$ & $\%$ & $\mathrm{~N}$ & $\%$ & $\mathrm{~N}$ & $\%$ & $\mathrm{~N}$ & $\%$ \\
\hline Keeping up with schoolwork & 4 & 50 & 1 & 12.5 & 1 & 12.5 & 2 & 25 & - & - \\
\hline $\begin{array}{l}\text { Missing school because of not } \\
\text { feeling well }\end{array}$ & 4 & 50 & - & - & 1 & 12.5 & 1 & 12.5 & 2 & 25 \\
\hline $\begin{array}{l}\text { Missing school to go to the doctor } \\
\text { or hospital }\end{array}$ & 1 & 12.5 & - & - & 3 & 37.5 & 3 & 37.5 & 1 & 12.5 \\
\hline Total & & & & & & & & & & \\
\hline
\end{tabular}

Fonte: PedsQL TM Questionário Pediátrico de Qualidade de Vida Versão 4.0 - Relato dos pais sobre as crianças (2 a 4 anos). 1998. 
Table 5. Frequency distribution of scores for school functioning. Fortaleza. CE. Brasil. (N=23).

\begin{tabular}{|c|c|c|c|c|c|c|c|c|c|c|}
\hline \multirow{2}{*}{$\begin{array}{l}\text { Social Functioning } \\
\text { (problems with...) }\end{array}$} & \multicolumn{2}{|c|}{ Never } & \multicolumn{2}{|c|}{ Almost never } & \multicolumn{2}{|c|}{ Sometimes } & \multicolumn{2}{|c|}{ Often } & \multicolumn{2}{|c|}{ Almost always } \\
\hline & N & $\%$ & $N$ & $\%$ & N & $\%$ & N & $\%$ & N & $\%$ \\
\hline Paying attention in class & 10 & 62.5 & 1 & 6.25 & 3 & 18.7 & 1 & 6.25 & 1 & 6.25 \\
\hline Forgetting things & 9 & 56.2 & 3 & 18.7 & 3 & 18.7 & 1 & 6.25 & - & - \\
\hline Keeping up with schoolwork & 6 & 37.5 & 1 & 6.25 & 1 & 6.25 & 3 & 18.7 & 5 & 31.2 \\
\hline $\begin{array}{l}\text { Missing school because of not } \\
\text { feeling well }\end{array}$ & 6 & 37.5 & 5 & 31.2 & 3 & 18.7 & 2 & 12.5 & - & - \\
\hline $\begin{array}{l}\text { Missing school to go to the doctor } \\
\text { or hospital }\end{array}$ & 2 & 12.5 & 1 & 6.25 & 7 & 43.7 & 2 & 12.5 & 4 & 25 \\
\hline Total & \multicolumn{2}{|c|}{33} & \multicolumn{2}{|c|}{11} & \multicolumn{2}{|c|}{17} & \multicolumn{2}{|c|}{9} & \multicolumn{2}{|c|}{10} \\
\hline
\end{tabular}

Regarding the school aspect, depicted in Table 5, it can be observed that $79.5 \%$ of the parents did not answer these questions because their children did not attend daycare and/or kindergarten. Of the total of eight children that attended daycare and/or kindergarten, 50\% never had problems when performing the same school activities of their classmates.

The frequency of treatment on an outpatient basis, as well as other diseases that result in hospitalization, make children with CP miss school days, so that three (37.5\%) reported that their children frequently missed school due to visits to the doctor or hospital, as well as aspects related to the disease, while three (37.5\%) answered that they had "sometimes" missed school in the previous month.

Of the total of 23 children aged between five and seven years, seven (30.4\%) did not answer questions related to the school domain, as they did not attend school. Of the 16 parents who completed the questionnaire, seven (43.7\%) "sometimes" had problems with school absenteeism as they had to take the child to the outpatient clinic or hospital; this occurred because of the chronic nature of the disease, which involves continuing follow-up of the child.

\section{Discussion}

About the socioeconomic characteristics, a similar study, which evaluated QoL of children with CP living in the South region, $50 \%$ of the sample had incomplete elementary education, in agreement with the present study that showed a low level of education, an indicator considered common for the Brazilian population reality [11].

The data regarding the parents' marital status are also similar to those in a previous study [12], which shows that having a child with CP may increase parental stress, but does not seem to increase the divorce rate, an aspect considered relevant in evolution of the treatment of children with CP.

The characterization of the study mothers is noteworthy, considering that there were more mothers than fathers, which is directly related to the parents' occupation, for most fathers were employed, while mothers were predominantly homemakers, with the latter being the responsible for taking the children to the health care service.

The mothers do not develop professional activities, but perform household chores; this fact can be understood as a consequence of the mothers' dedication to children with $\mathrm{CP}$, who need comprehensive care, depend on others and as the families cannot afford to pay caregivers to assist the children, they choose to provide home care. 
In a study carried previously [13] showed that half of the mothers of children with CP are homemakers and do not work outside the home. Personal problems experienced include loss of job, lack of concentration at work, loss of family joy, and derangement of financial affairs of the family. 26 (50\%) of them resort to religious/spiritual intervention as an alternative or complementary mode of treatment for their children while $28 \%$ resort to dependence on the extended family system for support [14].

Religion is another aspect that has implication in the phenomena related to health and sickness, in addition to the importance as a promoter of emotional, instrumental and informative support. In this sense, religion is a significant factor in the behavior and evolution of the disease in cases of children with $C P$, especially because the emotional aspect is intrinsically associated with QOL [15].

As a way to prevent disability progression in children with $\mathrm{CP}$, it is important to provide treatment assistance and guidance to parents in early intervention services, aiming to make them aware of their child's special needs. The intervention must be early to reach as soon as possible an immature brain capable of receiving normal sensations and integrate them into the growth process [16]; for this reason, some children are followed at more than one rehabilitation center, as shown in the present study.

Watching television was depicted as an important leisure activity, acting as a predictor of QoL in these children. Despite the aspects mentioned by the authors, it is necessary to emphasize that TV viewing can a fact that hinders the socialization of children with family members, as well as with other children. Given the above, it is prudent to involve children with CP in other activities, so that they may interact with the environment [17].

About the quality of life assessment, the school domain of children with CP was shown to be affected; that occurred because the disease required continuous monitoring, which resulted in frequent absenteeism when the child required medical care, an aspect that affects the student's performance in class. For children with chronic diseases, who live between the reality of school and hospitalizations, the challenge is to conciliate these two worlds, which directly affects QOL $[18,19]$.

As for the public school attendance of students with disabilities, it is emphasized that school participation is very low when compared to the rest of the population, even considering that the healthy population faces problems in some respects, similar to those faced by students with disabilities. This emphasizes the need for education for individuals with disabilities, due to their low school attendance, from elementary school to college/university level [20].

Among the obstacles to be overcome in the Brazilian public school system, aiming to the inclusion of children with CP and other individuals with special needs, the adequacy of a significant number of school facilities is required, as spaces and environments for individuals with motor deficits are not contemplated. Another challenge would be the training of teachers to deal with special needs students (SNS), as well as and the availability of basic materials and advanced technological resources and the presence of pedagogical practice that considers the diversity of educational needs [21]. Another factor considered harmful for the school performance aspect is the fact that CP sometimes results in delayed cognitive development in some children, hindering school activity achievement/monitoring.

Children with CP have several physical alterations that interfere with school performance and, therefore, it is necessary that teachers recognize how to deal with this specific situation. The teachers' initial and general formation should comprise curricular components that include studies and contents about students' potentials, especially those with special educational needs, as well as teaching practices to be adopted in the common classes of regular education. It is noteworthy that kindergarten teachers, in addition to teaching activities, also 
have the responsibility of care; this involves activities related to the child's daily life. When it comes to children with physical disabilities resulting from neurological lesions, the care process becomes complex [22].

Children with CP have a neurological lesion that causes a developmental delay of motion patterns, leading, in most cases, to the adoption of asymmetrical postures and joint range of motion limitations. Deformities can be classified as postural and positional, resulting in imbalance between muscle groups, joint and bone deformities and frequently, decreased bone density in children, who become unable to walk independently $[23,24]$. Musculoskeletal alterations result in impaired physical well-being of children with $C P$, especially regarding walking and running, as the results shown in the study.

The data were consistent with a study of individuals with neuromuscular diseases, which showed that even with the motor alterations, these individuals were able to adapt to new life circumstances without major psychosocial impairments, especially in diseases that develop early [25]. A study was carried out with families of children with and without disabilities in three US cities, Kansas, New Orleans and Granville, in relation to the social domain. In this research was reported their concern for their children, about negative comments in the context of social relations, describing past experiences, while others reported the priority in friendship relations because they were disabled [26].

The PedsQL tool measured the QOL in the month before the interview. Therefore, the data represented recent events, which minimizes potential recall bias. These findings show the importance of constantly assessing QOL, at different ages during the life of a child with a chronic disease, as the diagnosis changes according to disease evolution, thus characterizing different moments experienced by the child. Moreover, study adjustments are suggested in the assessment of QoL in the clinical follow-up, with standardized tools, such as the possibility of identifying the most critical areas of life, by offering parameters for better/specific care [27].

A limitation of this study includes the small sample size; however, the results demonstrate the relevance of such studies, which identify the influence of CP effects on children. The knowledge of these implications helps healthcare professionals to plan their actions aimed at improving QoL in several areas, especially the development of strategies with interdisciplinary involvement and participation of teachers, psychologists and professionals responsible for the rehabilitation process of these children.

Quality of life is a significant outcome measure in studies of patients with chronic diseases and, consequently, one has to consider, mainly, the choice of QOL assessment tool, which should be applied carefully to detect differences in each patient's life, considering that the data may affect the results and conclusions.

Intervention strategies should be implemented by the health professionals that work at different levels of care, aiming at providing qualified assistance to the child and the caregiver. It is understood that the diagnosis of CP usually represents an emotional burden for the child and the parents and can cause disorders such as depression, anxiety and others. This is a clear indication for the need for improvement in QoL standards, through direct participation in the child's consultations, such as early identification of alterations in motor patterns and the inclusion of these children in rehabilitation programs to promote overall physical and psychosocial adjustment.

\section{References}

1. The Definition and Classification of Cerebral Palsy. Dev Med Child Neurol. 2007; 49(s109):1-44. doi: 10.1111/j.14698749.2007.00001.x. [cited 200909 02]. Available from: http://www.fizjoterapeutom.pl/attachments/article/348/ Bax M 2007 The Definition and Classification of Cerebral Palsy.pdf. 
2. Rosenbaum $P$, Paneth $N$, Leviton $A$, Goldstein $M$, Bax $M$, Damiano D, Dan B, Jacobsson B. Dev Med Child Neurol Suppl. 2007 Feb;109:8-14. Erratum in: Dev Med Child Neurol. 2007 Jun; 49(6):480. [cited 200909 02]. Available from: http://www. ncbi.nlm.nih.gov/pubmed/17370477.

3. Whoqol Group. The World Health Organization quality of life assessment (WHOQOL): position paper from the World Health Organization. Social Science and Medicine. v. 10, p. 1403-1409, 1995. [cited 200901 07]. Available from: http://www.ncbi.nlm. nih.gov/pubmed/8560308.

4. Brasil, TB, Ferriani, VPL, Machado CSM. Health related quality of life survey about children and adolescents with juvenile idiopathic arthritis. J Pediatr (Rio J) 2003; 79(1):63-8. [cited 201008 02]. Available from: http://www.scielo.br/scielo. php?script=sci arttext\&pid=S0021-75572003000100011\&lng= en\&nrm=iso.

5. Prebianchi HB, Barbarini EH. Qualidade de vida infantil: limites e possibilidades das questões teórico-metodológicas. PsicoUSF, 2009; 14(3):355-364. [cited 200907 02]. Available from: http://www.scielo.br/scielo.php?script=sci arttext\&pid=S1413$82712009000300011 \& \operatorname{lng}=$ en\&nrm=iso.

6. LS Poeta, MFS Duarte, ICB Giuliano. Qualidade de vida relacionada à saúde de crianças obesas. Rev Assoc Med Bras 2010; 56(2): 168-72. [cited 201009 04]. Available from: http://www.scielo.br/scielo.php?script=sci arttext\&pid=S010442302010000200014\&lng=en\&nrm=iso.

7. Brasil, Ministério da Saúde. Política Nacional de Promoção da Saúde. Vol 7. Brasília: Ministério da Saúde, 2006. Available from: http://bvsms.saude.gov.br/bvs/publicacoes/politica promocao saude.pdf.

8. Barbosa TS, Mialhe FL, Castilho ARF de, Gavião MBD. Qualidade de vida e saúde bucal em crianças e adolescentes: aspectos conceituais e metodológicos. Physis, 2010; 20 (1): 283-300. [cited 201010 06]. Available from: http://www.scielo.br/scielo. php?script=sci arttext\&pid=S0103-73312010000100015\&lng= en\&nrm=iso

9. Varni JW, Seid M, Kurtin PS. The PedsQL 4.0: reliability and validity of the Pediatric Quality of Life Inventory Version 4.0 Generic Core Scales in healthy and patient populations. Med Care. 2001; 39(8):800-812. [cited 201008 02]. Available from: http://www.ncbi.nlm.nih.gov/pubmed/11468499.

10. Klatchoian DA, Len CA, Terreri MTRA, Silva M, Itamoto C, Ciconelli RM. et al. Qualidade de vida de crianças e adolescentes de São Paulo: confiabilidade e validade da versão brasileira do questionário genérico Pediatric Quality of Life InventoryTM versão 4.0. J. Pediatr. 2008; 84(4):308-315. [cited 201008 02]. Available from: http://www.ncbi.nlm.nih.gov/ pubmed/11468499.
11. Morales NMO, Silva, CHM, Frontarolli AC ; Araújo RRH, RangeL VO, Pinto RMC, Gomes DC. Psychometric properties of the initial Brazilian version of the CHQ-PF50 applied to the caregivers of children and adolescents with cerebral palsy. Quality of Life Research 2007; 16:437-444. [cited 201109 02]. Available from: http://www.ncbi.nlm.nih.gov/pubmed/1733483.

12. Forman MA. The family of the child with brain injury. In: Braga, L.W. e Campos da Paz (Orgs). The child with Traumatic Brain Injury or Cerebral Palsy, London: Taylor e Francis Group, p. 217 227, 2006.

13. Corbella MB. Estrés y afrontamiento en familias con hijos afectados de parálisis cerebral. Boletín de Noticias del Instituto Universitario de Integración en la Comunidad, 2002; 5(14): 1-15. [cited 201003 07]. Available from: http://gredos.usal.es/jspui/ handle/10366/115503.

14. Olawale OA, Deih AN, Yaadar RK. Psychological impact of cerebral palsy on families: The African perspective. Journal of Neurosciences in Rural Practice. 2013;4(2):159-163. [cited 201403 07]. Available from: http://www.ncbi.nlm.nih.gov/ pubmed/23914092.

15. Faria, JB, Seidl, EMF. Religiosidade e enfrentamento em contextos de saúde e doença: revisão da literatura. Psicologia: Reflexão e Crítica, 2005; 18(3), 381-389. [cited 201009 06]. Available from: http://www.scielo.br/scielo.php?script=sci arttext\&pid=S0102-79722005000300012\&lng=en\&nrm=iso .

16. Maltais DB, Wiart L, Fowler E, Verschuren O, Damiano DL. Health-related physical fitness for children with cerebral palsy. Journal of child neurology. 2014;29(8):1091-100. [cited 201510 06]. Available from: http://www.ncbi.nlm.nih.gov/ pubmed/24820339.

17. Melo ELA, Valdés MTM. Evalución de la calidad de vida de los niños com distrofia muscular progressiva de Duchenne. Rev Neurol., 2007;45(2):81-87. [cited 201010 06]. Available from: https://www.researchgate.net/publication/236759950 Evaluacion de la calidad de vida de ninos con distrofia muscular progresiva de Duchenne.

18. Melo ELA, Valdés MTM, Bezerra MHO et. al. Qualidade de Vida na infância: aspectos conceituais e pragmáticos. Rev Tend Enferm Prof, 2009; 1(1): 43-6.

19. Holanda ER, Collet N. Escolarização da criança hospitalizada sob a ótica da família. Texto \& Contexto Enferm., 2012; 21( 1 ): 34-42. [cited 201309 06]. Available from: http://www.scielo.br/scielo. php?script=sci arttext\&pid=S0104-07072012000100004\&lng =en\&nrm=iso 
20. Kasper AA, Loch MVP, Pereira VLDV. Alunos com deficiência matriculados em escolas públicas de nível fundamental: algumas considerações. Educar em Revista. 2008; (31), 231-243. [cited 201007 06]. Available from: http://www.scielo.br/scielo. php?script=sci arttext\&pid=S0104-40602008000100014\&lng $=e n \& n r m=$ iso

21. Gomes C, Barbosa AJG. Inclusão escolar do portador de paralisia cerebral: atitudes de professores do ensino fundamental. Revista Brasileira de Educação Especial., 2006;12(1), 85-100. [cited 200910 06]. Available from: http://www.scielo.br/scielo. php?script=sci arttext\&pid=S1413-65382006000100007\&Ing $=e n \& n r m=i s o$

22. Melo, FRLV, Ferreira CCA. O cuidar do aluno com deficiência física na educação infantil sob a ótica das professoras. Revista Brasileira de Educação Especial. 2009; 15(1), 121-140. [cited 201004 08]. Available from: http://www.scielo.br/scielo. php?script=sci arttext\&pid=\$1413-65382009000100009\&Ing $=e n \& n r m=i s o$

23. Michael S, Porter D, Pountney T. Tilted seat position for nonambulant individuals with neurological and neuromuscular impairment: a systematic review. Clinical Rehabilitation. 2008;21(12):1063-1074. [cited 200907 03]. Available from: http://www.ncbi.nlm.nih.gov/pmc/articles/PMC2630001/.

24. Berker $N$, Yalçin S. The help guide to cerebral palsy. $2^{\text {nd }}$ ed. Rotama Press: Washington. 2010. 1-148.

25. Piccininni, M.; Falsini, C.,Pizzi, A. Quality of life in hereditary neuromuscular diseases. Acta Neurological Scadinavica, v.109, p.113-119, 2004. [cited 200907 03]. Available from: $\quad$ http://onlinelibrary.wiley.com/doi/10.1046/i.16000404.2003.00185.x/pdf.

26. Poston D, Turnbull A, Park J, Mannan H, Marquis J, Wang M. Family quality of life: a qualitative inquiry. Ment Retard. 2003;41(5):313-28. [cited 200907 09]. Available from: https:// kuscholarworks.ku.edu/handle/1808/6055.

27. Santos ECM, França-Júnior I, Lopes F. Qualidade de vida de pessoas vivendo com HIV/Aids em São Paulo. Rev Saúde Pública. 2007; 41(Suppl 2): 64-71. [cited 2016-09-06]. Available from: http://www.scielo.br/scielo.php?script=sci arttext\&pid=S0034$\underline{89102007000900011 \& \operatorname{lng}=e n \& n r m=i s o}$
Publish in International Archives of Medicine

International Archives of Medicine is an open access journal publishing articles encompassing all aspects of medical science and clinical practice. IAM is considered a megajournal with independent sections on all areas of medicine. IAM is a really international journal with authors and board members from all around the world. The journal is widely indexed and classified Q2 in category Medicine. 